\title{
Diversity, distribution and conservation status of fish of the genus Garra (Cypriniformes: Cyprinidae) from the Kaladan drainage of Mizoram, northeastern India
}

\author{
Beihrosa Solo ${ }^{\text {I*, Lalnuntluanga }}{ }^{2}$

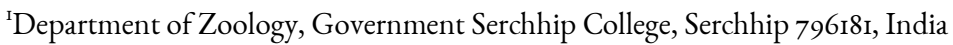 \\ ${ }^{2}$ Department of Environmental Science, Mizoram University, Aizawl 796004, India.
}

\begin{abstract}
The present study was carried out on the diversity of fish under the genus Garra from the Kaladan River and its tributaries of Mizoram, northeast India. The study reported the occurrence of seven species viz. Garra flavatra, G. cf. koladynensis, G. cf. matensis, G. nigricolis, G. rakhinica, G. manipurensis and G. khawbungi. Key to Garra species from Kaladan River drainage of Mizoram and their brief descriptions are given.
\end{abstract}

Keywords: Biodiversity hotspot, distribution, Garra, Indo-Myanmar, Kaladan.
Received 12 October 2018 Accepted 24 November 2018

*For correspondence $\bowtie$ : beihrosasolo@yahoo.com

\section{INTRODUCTION}

The genus Garra Hamilton-Buchanan has been reviewed by Menon, ${ }^{1}$ who recognized 37 species. Seven species under the genus Garra have also been reported from southern Myanmar. ${ }^{2}$ The major revision of the Garra species have been carried out by Menon ${ }^{1}$ and Getahun. ${ }^{3}$ The genus is widely distributed in southern China, south east Asia, India, middle east to northern and central Africa and comprises a total of 60 species out of which 40 species are from Asia. ${ }^{3}$ Kotellat reported the occurrence of 64 Garra species. ${ }^{4}$ However, recent works on Garra by Nebeshwar and Vishwanath highlighted the distribution of at least 79 species in China, South East Asia, India and Sri Lanka. ${ }^{5}$ The possession of suctorial disc on the ventral surface of the head, just behind the mouth is an important character of the genus. ${ }^{5}$ Most of the Garra species inhabit rapid running waters and adapt to the substratum by means of horizontally placed paired fins called the pectorals. ${ }^{1}$

Species belonging to the genus Garra have been recorded from different locations of Mizoram by different authors including the description of new species. ${ }^{5-9}$ The present study aim to highlight a comprehensive report of Garra species from the Kaladan drainage of Mizoram, their distribution and conservation status.

\section{MATERIALS AND METHODS}

Specimens were collected from the Kaladan River of Mizoram and its tributaries viz. Sala, Ngengpui, Tuisi, Tuichang, Mat and Tiau Rivers (Table 1). Field collections were carried out three times a year to ensure maximum fish collection from 2013 to 2018. Specimens were preserved in 


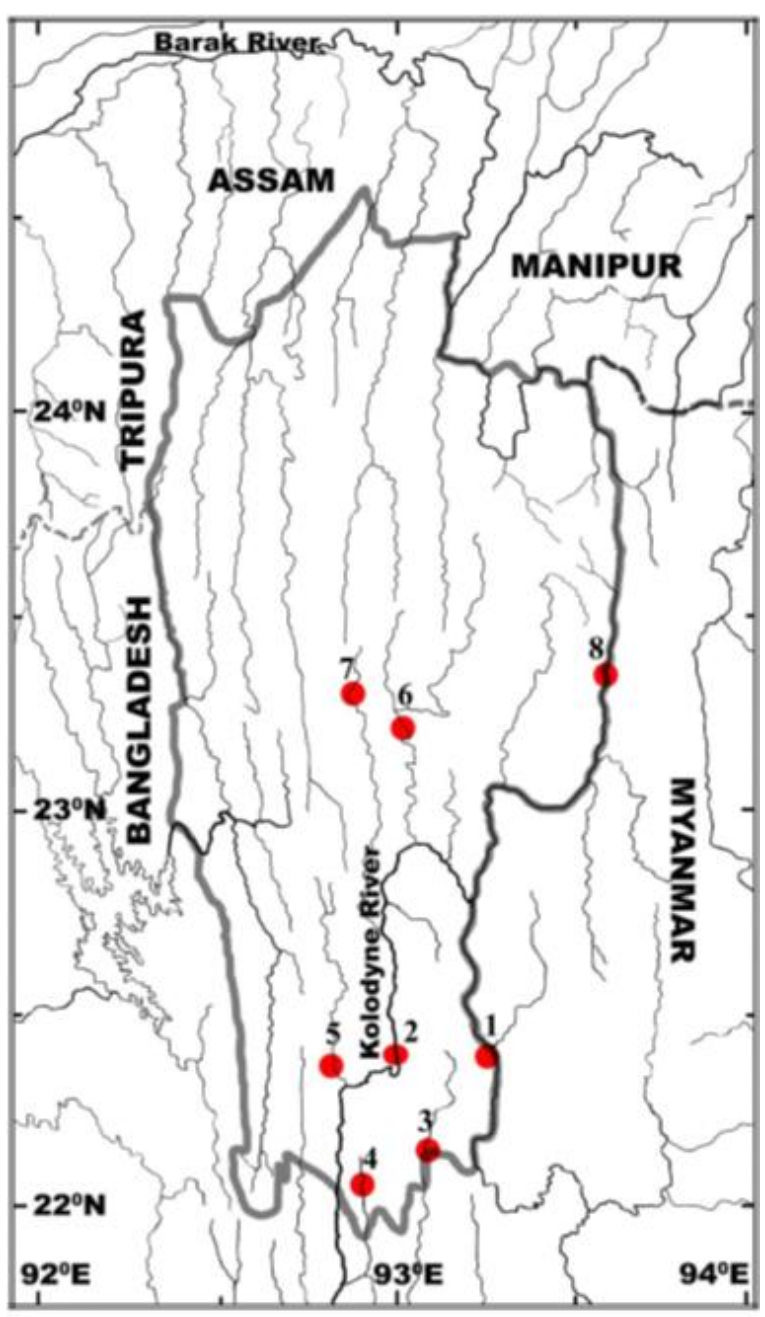

Figure 1 | Drainage map of Mizoram showing permanent sampling stations. Number in map corresponds to sampling stations given in Table 1 and 2 .
$10 \%$ formalin solution.

For counts and measurements, relevant research papers were followed., ${ }^{2,10}$ Measurements were taken on the left side of the specimens to the nearest $0.1 \mathrm{~mm}$ using digital calipers. Body measurements are expressed as percentages of standard length (\% SL) and head measurements as percentages of head length (\% HL). The specimen collected were deposited in the Zoological Museum of Fish (PUCMF), Department of Zoology, Pachhunga University College, Aizawl, Mizoram.

\section{RESULT}

A total of 7 species under the genus Garra were identified from the selected rivers of Kaladan drainage which comes under 5 different conservation status as assessed by IUCN red list (2018) as in Figure 2. The distribution and conservation aspects of each Garra species can be observed from Table 2. Key to Garra species from Kaladan drainage of Mizoram is given for easy identification.

\section{Garra flavatra Kullander \& Fang, 2004 (Figure 3)}

\section{Material examined: PUCMF 12062 Description}

A small species of Garra with elongated body, predorsal contour of body ascending from snout to dorsal-fin origin and posteriorly descending but only less deep. Chest and abdomen scaled including predorsal regions. Snout rounded presence of

Table 1 | List of sampling sites.

\begin{tabular}{lllll}
\hline SI. No. & Sampling sites & River & Location & District \\
\hline 1. & Site 1 & Kaladan & Vicinity of Lungbun & Saiha \\
\hline 2. & Site 2 & Kaladan & Vicinity of Kawlchaw & Saiha \\
\hline 3. & Site 3 & Tuisi & Vicinity of Khopai & Saiha \\
\hline 4. & Site 4 & Sala & Vicinity of Lungpuk & Saiha \\
\hline 5. & Site 5 & Ngengpui & Vicinity of Khawmawi & Lunglei \\
\hline 6. & Site 6 & Mat & Vicinity of Serchhip & Serchhip \\
\hline 7. & Site 7 & Tuichang & Vicinity of Keitum & Serchhip \\
\hline 8. & Site 8 & Tiau & Vicinity of Zokhawthar & Champhai \\
\hline
\end{tabular}


Table 2 | List of Garra fish species collected, distribution and conservation status as assessed by IUCN Red List (2018) on Kaladan, Tuisi, Sala, Ngengpui, Mat, Tuichang and Tiau river.

\begin{tabular}{|c|c|c|c|c|c|c|c|c|c|}
\hline \multirow{2}{*}{$\begin{array}{l}\text { SI. } \\
\text { No }\end{array}$} & \multirow[t]{2}{*}{ Name of species } & \multicolumn{7}{|c|}{ Name of the rivers } & \multirow{2}{*}{$\begin{array}{l}\text { IUCN } \\
\text { Status }\end{array}$} \\
\hline & & Kaladan & Tuisi & Sala & Ngengpui & Mat & Tuichang & Tiau & \\
\hline 1 & Garra flavatra & & + & & & & & & VU \\
\hline 2 & Garra cf. koladynensis & + & + & & & + & + & & NE \\
\hline 3 & Garra cf. matensis & & + & + & + & & & & $\mathrm{NE}$ \\
\hline 4 & Garra nigricollis & & & + & & & + & & DD \\
\hline 5 & Garra rakhinica & + & + & + & + & + & + & + & NT \\
\hline 6 & Garra manipurensis & + & + & + & + & + & + & + & VU \\
\hline 7 & Garra cf. khawbungi & + & + & + & & + & + & + & NE \\
\hline
\end{tabular}

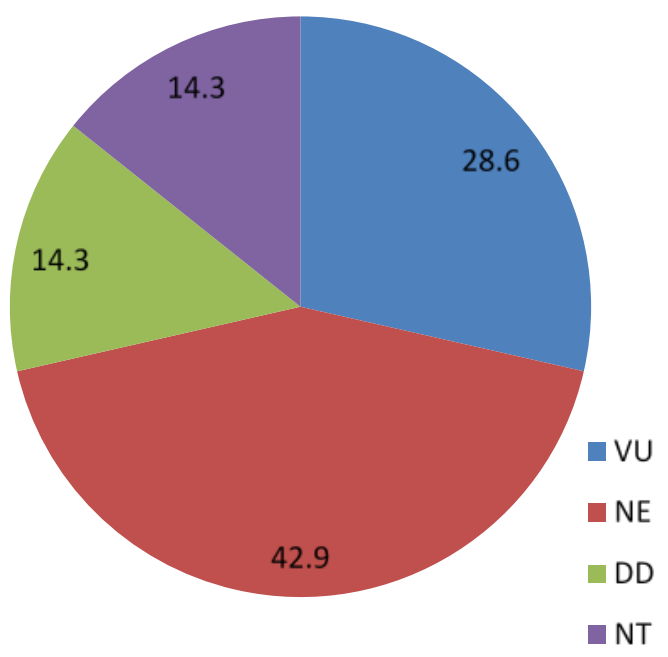

Figure 2 | IUCN red list (2018) criteria of the Garra species collected in percentage.

slight transverse groove. Rostral lobe present, conical tubercles on rostral lobe and snout. Presence of two pairs of barbel. Dorsal fin with 2 -3 simple, 7 -7 $1 / 2$ branched rays insertion anterior to pelvic-fin origin. First unbranched ray longest, extent to almost anal-fin origin. Pectoral fin with 1 simple and 12-14 rounded, inner rays forming straight margin, fifth branched ray longest, not extending to base of pelvic-fin. Pelvic fin with 1 simple, 8 branched ray with blunt tip, inner rays forming straight margin, second branched ray longest, not extending to base of anal fin. Anal fin short, subacuminate with 2 simple $4 \frac{1}{2}$ branched rays, first branched ray longest, tip extending slightly beyond base of caudal fin. Caudal fin with 10-9+9 rays, emarginated, both lobes of equal length, tip rounded, infra-marginal band along posterior margin, black on lobes, dark grey on middle rays; two vertical row s of irregular black spots across middle of fin. Lateral line scale complete with $28-29+2$ scales, lateral transverse scale in transverse rows $1 / 23 / 1 / 3$. Circumpeduncular scale 16.

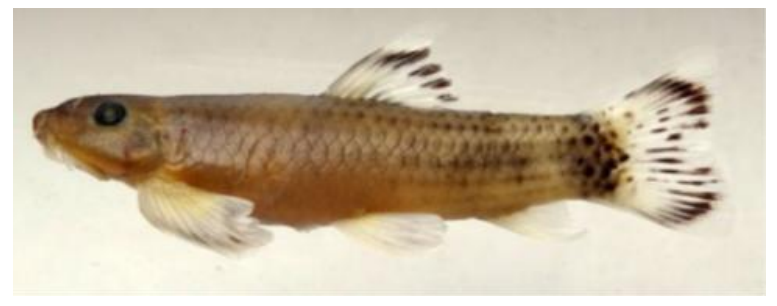

Figure 3 | Garra flavatra.

Garra cf. koladynensis Lokeshwor \& Vishwanath, 2012 (Figure 4)

\section{Material examined: PUCMF 14054 Description}

Snout rounded with 9-13 medium size tubercles, transverse lobe present, prominent proboscis with shallow depression in middle that gives bilobed appearance moderately elevated upwards. 
Body elongated, compressed laterally till caudal peduncle region. Dorsal profile of body ascending slightly to dorsal-fin origin, ventral profile of body more or less straight to anal-fin origin. Head region moderately depressed and large. Eyes placed in dorsolateral posterior part of head. Barbels occur in two pair, maxillary barbel and rostral barbel. Upper jaw covered by thin rostral cap disc, elliptical, shorter than wide. Dorsal fin with 2-3 simple, 8 1/2 branched rays inserted anterior to vertical from pelvic-fin origin, first branch ray longest. Pectoral fin with 1 simple and 14-15 branch rays reaching beyond midway to pelvic-fin origin. Pelvic fin with 1 simple and $7 \frac{1}{2}$ branch rays, reaching beyond midway to anal fin-origin. Anal fin with 2 simple, $5 \frac{1}{1} 2$ branch rays, first branched ray longest, reaching base of caudal-fin base. Caudal fin with $9-10+9$ rays, forked, tips pointed lobes of equal length. Lateral line complete with $31-32+2-3$ scales and the lateral scale in transverse row is $1 / 24-4 / 1 / 3$.

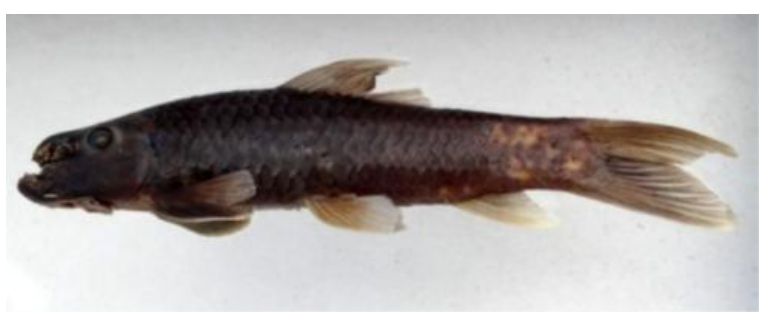

Figure 4 | Garra cf. koladynensis.

Garra cf. matensis Nebeshwar \& Vishwanath, 2017 (Figure 5)

\section{Material examined: PUCMF 14040 Description}

Body moderately short and rounded. Snout semi-circular; blunt; absence of transverse groove and proboscis. Presence of few tubercles on snout and cheek. Head moderately compressed, interorbital region slightly convex. Dorsal profile of body ascends slightly from snout to dorsal-fin origin and become almost straight at dorsal-fin origin there- after sloping down towards caudal peduncle. Ventral profile of body almost straight from pectoral fin to pelvic-fin origin. Predorsal region scaled absence of scale on chest and abdominal portion. Dorsal fin with 2 simple, 6 branched rays, presence of dark streak or bar near free margin of dorsal fin. Pectoral fin with 1 simple 14-16 branched rays. Anal fin with 2 simple, $4 \frac{1}{2}$ branched rays and short. Pelvic fin with 1 simple, $61 / 2-7 \quad 1 / 2$ branched rays. Predorsal scale 13-14. Caudal fin with 10+9 (9+8 branched) rays. Presence of thin, light black $W$ - shaped band on posterior half of caudal fin. Upper and lower lobe of caudal fin of equal length. Lateral line complete with $30-31+2$ scales. Lateral line scales in transverse row $1 / 23-4 / 1 / 3$; circumpeduncular scale 16. Presence of 1 pair of barbel.

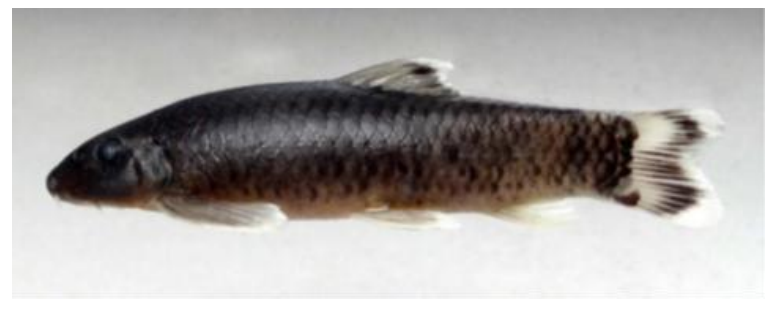

Figure 5 | Garra cf. matensis.

Garra nigricollis Kullander \& Fang, 2004 (Figure 6)

\section{Material examined: PUCMF 12058 Description}

Moderately large species of Garra, with elongated body, predorsal contour ascending about straight up to dorsal fin and posteriorly, only slightly less deep. Ventral surface of head and chest flattened, abdomen appears rounded. Presence of black band across posterior margin of head, between left and right side of pectoral-fin base. Snout rounded with appearance of shallow transverse groove, presence of short rostral lobe. Snout tip and rostral lobes demarcated by presence of pointed tubercles. Central pad wider than long, 
short papiliferous fold extending from corner of mouth between exposed lower jaw and upper lip. Dorsal fin inserted anterior to pelvic fin-origin, falcate with 2 simple and $81 / 2$ branched rays. Pectoral fin with 1 simple, 16 branched rays, sub acuminate, fourth branch ray longest but not extending up to pelvic-fin base. Pelvic fin with 1 simple $7 \quad$ 1/2 branched rays, sub acuminate, first branch ray longest, margin not extending beyond anal-fin base. Anal fin with 2 simple, $51 / 2$ branched rays, short, subacuminate, first branched ray longest, margin extending beyond base of caudal-fin origin. Caudal fin with 9-10+9 rays, deeply emarginated, lobe pointed. Lateral line scale $32-34+3$, lateral line scale in transverse rows $4 / 1 / 3$. Predorsal scale 10 12; circumpeduncular scales 16 . Chest scale between pectoral fin deeply embedded in skin. Presence of indistinct dark grey rounded blotch on posterior side of caudal peduncle.

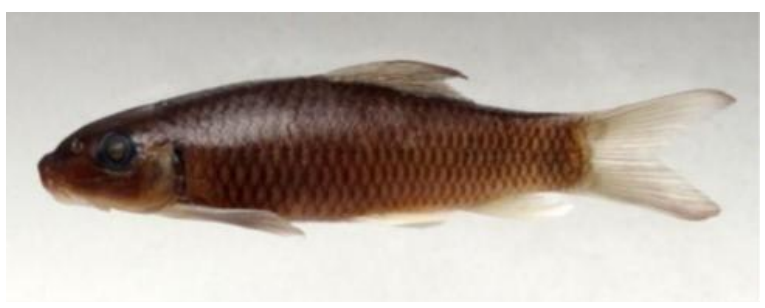

Figure 6 | Garra nigricollis.

Garra rakhinica Kullander \& Fang, 2004

(Figure 7)

\section{Material examined: PUCMF 13066/14039//13068 Description}

Body elongated, predorsal contour ascend up to dorsal-fin origin and descent towards deep caudal peduncle. Ventral surface flat, scaled from head to chest and belly, become rounded towards posterior end of pelvic fin insertion. Snout rounded, tip portion embedded with tubercles. Two pairs of barbel present. Rostral lobe present on snout, proboscis absent. Anterior barbel short, flattened, not extend- ing to margin of rostral cap. Central pad in lower lip slightly wider than long. Dorsal-fin origin anterior to pelvic-fin origin. Dorsal fin falcate, long subacuminate tip with 2 simple and 8 branch fin rays. Anal fin with 2-3 simple, 5 branched rays, short with straight posterior margin, first branched ray longest, extending slightly beyond base of caudal fin. Pectoral fin with 1 simple, 15 branched ray, subacuminate, fourth branched ray longest. Caudal fin with $10+9$ rays, emarginated, lobes equal, tips blunt, of a distinct $w$ shaped dark band. Pelvic fin with 1 simple, 8 branched rays. Circumpeduncular scales 16 . Lateral line complete with $29+1-2$ scales. Lateral transverse scales 3/1/2-3.

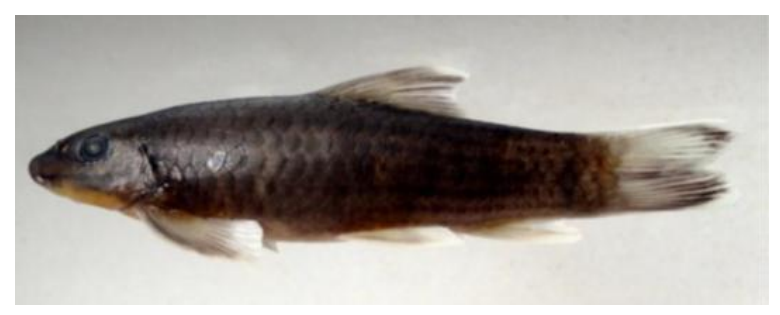

Figure 7 | Garra rakhinica.

Garra manipurensis Vishwanath \& Sarojnalini, 1988 (Figure 8)

\section{Material examined: PUCMF 12042/13069 Description}

Body moderate to small, elongated, predorsal contour slightly ascending from snout to base of dorsal-fin origin thereafter sloping slightly towards caudal peduncle. Ventral profile of body flattened from head to anal-fin base then slightly sloping towards caudal peduncle. Snout rounded absence of transverse groove, presence of minute pointed tubercles at tip. Orbit moderately large, located at centre of head. Rostral lobe present with 2-3 tubercles in smaller specimen but 7-8 tubercles in large specimen. Narrow band of papiliferous tissue occurs along upper jaw, central pad wider than long. 
Dorsal fin with 3 simple, $8 \frac{1}{2}$ branched rays, smoky, second branched ray longest and presence of black streak on interradial membrane. Dorsal-fin origin anterior to pelvic-fin origin. Pectoral fin with 8-9 simple, 10-11 branched rays, smoky, rounded, eight branched ray longest, not extending to pelvic-fin origin with white margin to anterior ray tips. Pelvic fin with 2 simple $81 \frac{1 / 2-9}{1 / 2}$ branched rays, smoky, rounded tip, third branched ray longest, not extending to base of anal-fin origin. Anal fin with 3 simple $51 / 2$ branched rays; short, subacuminate, second branched ray longest and tips extending towards caudal-fin base but not reaching it. Caudal fin with $10+9$ principal rays $(9+8)$ branched rays, slightly emarginated, lobe tips slightly rounded, both lobes of equal length. Predorsal region with 19-20 scales. Chest scale deeply embedded in skin. Circumpeduncular scale consisted of 16-18 scales. Lateral line complete with $30-33+2$ scales, lateral line scales in transverse row $1 / 24 / 1 / 3$.

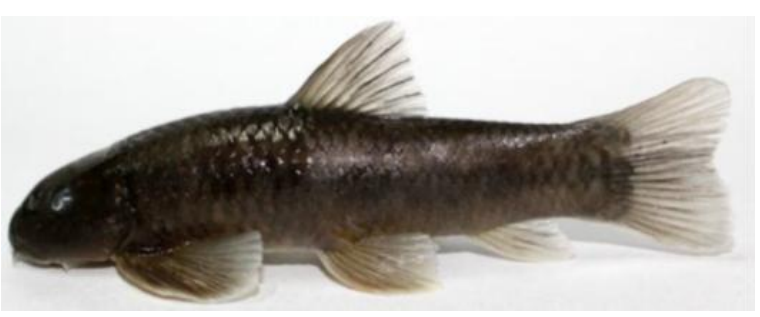

Figure 8 | Garra manipurensis.

Garra cf. khawbungi Arunachalam, Nandagopal \& Mayden, 2014

(Figure 9)

\section{Material examined: PUMF 13063/1406 Description}

Body elongated, almost cylindrical, generally not compressed towards posterior part of body to dorsal-fin base. Dorsal profiles of body shows gradual ascend up to dorsal-fin base then remain straight towards caudal fin. Ventral profile of body from pectoral-fin origin to pelvic-fin origin show convex appearance, from pelvic-fin origin to analfin origin remains straight. Head large; interorbital region convex. Snout rounded from dorsal view, shorter, not elongated as proboscis, presence of weak transverse groove with pointed tubercles arranged irregularly as three rows on each side. Two pairs of barbells; maxillary and rostral barbels present. Rostral cap well developed, cover entirely upper jaw region. Central pad elliptical shape with width greater than length. Dorsa fin with 2-3 simple, 8 branched rays; origin slightly anterior to pelvic fin-origin, first branched dorsal fin ray longest. Pectoral fin with 1 simple, 16 branched ray with slightly pointed posterior margin, fin insertion close to gill opening region, fourth branch ray longest. Pelvic fin with 1 simple, 8 branched ray, posterior margin not reaching anal-fin origin but covers anus region. Anal fin with 2 simple, 5 branched rays; posterior margin not reaching base of caudal fin. Caudal fin with 9+8 branch rays, forked, both upper and lower lobe of equal length. Lateral line complete with $32-33+2$ scales. The lateral line scales in transverse row $1 / 23-4 / 1 / 2$. Circumpeduncular scale 16 , predorsal scale $9-10$.

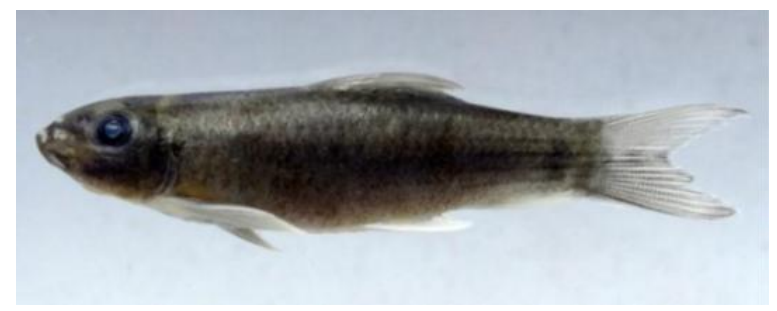

Figure 9 | Garra cf. khawbungi.

\section{Discussion}

The present study from various sites revealed the presence of at least seven Garra species from seven rivers contributing to different 4 IUCN categories (Table 2 and Figure 8). Of the species collected, Garra flavatra and G. manipurensis comes under vulnerable category under IUCN criteria and accounts for $28.6 \%$ each of the overall Garra spe- 
cies collected. Two Garra species, Garra nigricolis and G. rakhinica contributes $14.3 \%$ each and comes under data deficient and near threatened categories whereas G. cf. matensis, G. cf. khawbungi and $G$. cf. koladynensis comes under not evaluated IUCN category and contributes $42.9 \%$ of the overall Garra species collected. Of these, G. flavatra and G. nigricollis seems to be of rare occurrence as they were collected from just one or two study sites whereas G. rakhinica and G. manipurensis shows dominant distribution in all the study sites.

Garra rakhinica, G. flavatra and G. nigricollis were originally described and reported that their occurrences are restricted to Rakhine, Yoma (Myanmar). ${ }^{2} \mathrm{~A}$ closer inspection reveals that there is a chance of connection of Rakhine and Kaladan basin at Sittwe, Myanmar. Therefore, the specimens identified as G. rakhinica, G. flavatra and G. nigricollis expand their distributional range. Two new species of Garra, G. khawbungi and G. tyao have also been described recently from Tuipui and Tiau river of Mizoram. ${ }^{10}$ Garra khawbungi is closely related to $G$. nigricollis but differs from it by having more lateral-line scales, fewer predorsal scales, fewer caudal-fin rays, presence of a transverse groove on snout and absence of a black band across the posterior margin of the head. and between right and left side of pectoral-fin bases. After carefully studying the description of the reported new species, Garra tyao, from Tiau River (Tyao River) of Kaladan basin ${ }^{10}$ seemingly belongs to $G$. rakhinica as no distinct variation is observed between G. tyao and G. rakhinica.

The diagnostic characters of Garra tyao from $G$. rakhinica, given by Arunachalam et al. ${ }^{10}$, are that $G$. tyao have more number of lateral line scales (31 vs. 27-29 in G. rakhinica), fewer branched caudal-fin rays $(9+8$ vs. $10+9$ in $G$. rakhinica) and the presence (vs. absent in G. rakhinica) of 'W'- shaped dark band on the caudal fin. The higher count of the lateral line scales in G. tyao is attributed to the difference in the counting method in which Kullander and Fang ${ }^{2}$ counted only scales on the body for $G$. rakhinica whereas Arunachalam et al. ${ }^{10}$ followed Hubbs $\&$ Lager $^{12}$, and the difference in caudal-fin rays is attributed to the method of counting of fins as Kullander and Fang ${ }^{2}$ counted the principal caudal rays for $G$. rakhinica whereas Arunachalam et $a .^{10}$ presented the branched caudal rays for $G$. tyao. Besides, the presence (vs. absent in G. rakhinica) of ' $W$ '- shaped dark band on the caudal fin is attributed to the difference in color description by the authors. ${ }^{2,9,12} \mathrm{~A}$ closer inspection of the caudal fin photograph (Fig. 5C of Arunachalam et al. ${ }^{10}$ ) is exactly similar to the color of the caudal fin of $G$. rakhinica defined by Kullander and Fang ${ }^{2}$. Besides, an important diagnostic character of G. rakhinica, the blackish horizontal stripe from base of anterior barbel to preopercle is not mentioned in the description of $G$. tyao but can be clearly seen in the photograph (Fig. 5A of Arunchalam et al. ${ }^{10}$ ). These comparisons also coincide with the recent report on G. rakhinca from Kaladan River. ${ }^{5}$ Therefore, keeping in mind the aforesaid account of the overall similarity between the two nominal species, we hereby considered Garra tyao, a junior synonym of G. rakhinica.

Several species of Garra had been recorded from different locations of Mizoram by different authors. ${ }^{5-8}$ The occurence of Garra species from Kaladan river by some authors also includes Garra annandalei Hora, Garra gotyla gotyla (Gray), Garra naganensis, Garra matensis and Garra sp. ${ }^{7,8}$ Lalronunga et al. ${ }^{9}$ described G. dampaensis from Seling River (tributary of Karnaphuli River) within Dampa Tiger Reserve. The species have a dark streak near the free margin of the dorsal fin, W-shaped band on the caudal fin and is among the Lissorhynchus complex of Menon. ${ }^{1}$ Though some authors reported the occurrence of Garra naganensis from Kaladan river ${ }^{7,8}$, none of the species collected from the study sites resemble the species mentioned by them.

Key to Garra species of the Kaladan drainage of Mizoram is given as follows:

1. Transverse groove present .......................... 3

2. Transverse groove absent ........................... 5

3. Weak transverse groove on snout G. khawbungi

4. Deep transverse groove on snout 
G. koladynensis

5. Lateral line scale $28-29$ 6

6. Presence of vertical dark bars on dorsal fin .G. flavatra

7. Absence of vertical dark bar on dorsal fin 8

8. Presence of dark horizontal stripe from base of anterior barbel to preopercle

G. rakhinica

9. Lateral line scale 30-31 10

10. Presence of $W$ shape dark band on caudal fin G. matensis

11. Absence of dark bands on dorsal or caudal fins G. manipurensis

12. Lateral line scale 33 . .13

13. Presence of black band across posterior margin of the head ..G. nigricollis

\section{REFRENCES}

I. Menon, A.G.K. (1964). Monograph of the cyprinid fishes of the genus Garra Hamilton. Memoirs of Indian Museum 14,173-260.

2. Kullander, O. \& Fang, F. (2004). Seven new species of Garra, (Cyprinidae: Cyprininae) from the Rakhine Yoma, southern Myanmar. Ichthyological Exploration of Freshwaters 15, 257-278.

3. Getahun, A. (2000). Systematic studies of the African species of the genus Garra (Pisces: Cyprinidae). Unpublished doctoral dissertation, City University of New York. pp. 478.

4. Kotellat, M. (2013). The fishes of the inland waters of Southeast Asia: A catalogue and core bibliography of the fishes known to occur in freshwaters, mangroves and estuaries. Raffles Bulletin of Zoology (Supplement) $27, \mathrm{I}-663$.
5. Nebeshwar, K. \& Vishwanath, W. (2017). On the snout and oromandibular morphology of genus Garra, description of two new species from the Koladyne River basin in Mizoram, India and redescription of G. manipurensis (Teleostei: Cyprinidae). Icthyological Exploration of Freshwaters 28, 17-53.

6. Vishwanath,W. \& Shanta Devi, K. (2005). A new fish species of the genus Garra Hamilton-Buchanan (Cypriniformes: Cyprinidae) from Manipur, India. Journal of the Bombay Natural History Society 102, 8688.

7. Karmakar, A.K. \& Das, A. (2007). Fishes. Fauna of Mizoram, State Fauna Series 14 part I. Zoological Survey of India, Kolkata. 69ipp.

8. Kar, D. \& Sen, N. (2007). Systematic list and distribution of fishes in Mizoram, Tripura and Barak drainage of northeastern India. Zoos Print Journal 22, 25992607.

9. Lalronunga, S., Lalnuntluanga \& Lalramliana (2013). Garra dampaensis, a new ray- finned fish species (Cypriniformes: Cyprinidae) from Mizoram, northeastern India. Journal of Threatened Taxa 5, 4368-4377.

Io. Arunachalam, M., Nandagopal, S. \& Mayden, R.L. (20I4). Two new species of Garra from Mizoram, India (Cypriniformes: Cyprinidae) and a general comparative analysis of Garra. Species 10, 58-78.

II. Talwar, P.K. \& Jhingran, A.G. (1991). Inland fishses of India and adjacent countries. Vol. 2., Oxford and IBH publishing company Ltd., New Delhi, India, II58 pp.

12. Hubbs, C.L. \& Lagler, K.F. (1964). Fishes of the Great Lakes Region. Ann Arbor: University of Michigan press. pp. 213. 